\title{
Laughing All the Way to the Bank: Using Television Clips to Promote Financial Literacy
}

\author{
EMILY MROSS \\ Penn State Harrisburg \\ elm43@psu.edu
}

\section{TEACHING AND LEARNING}

\begin{abstract}
International students, who comprise $14.5 \%$ percent of the student body at Penn State Harrisburg, expressed concern regarding personal finances in an institutional survey. Using situational comedy clips that addressed financial missteps, the author worked with an English conversation group to discuss personal finance management and financial assistance resources and to promote financial literacy amongst the students based on the Reference and User Services Association's Financial Literacy Education in Libraries: Guidelines and Best Practices for Service. The use of sitcoms allowed humor to lighten what can often be a taboo subject. The clips provided examples to critique rather than using personal experiences. Students reacted positively to the program structure and participated in lively conversation.
\end{abstract}

Keywords financial literacy, academic libraries, library programs, public services, outreach services

Penn State Harrisburg, a suburban college with 5,000 students, serves over 700 international students (Penn State University Budget Office, 2019). An internal survey conducted by the campus Office of International Student Support Services (ISSS) to determine challenges perceived by the international students found that finances were the third-highest concern after academic performance and time management for Harrisburg's international graduate students. In addition, a focus group of the Penn State Harrisburg international student population (both graduate and undergraduate) found financial issues were common among the group (Poyrazli \& Grahame, 2007). Studies of international students find their financial stress is high due to reliance on family financial support, lack of access to scholarships and institutional funding, and/or the inability to work legally for additional money (Yan \& Berliner, 2013; Smith \& Khawaja, 2011; Myers-Walls, Frias, Kwon, Ko, \& Lu, 2011). Though international students may have concerns about their finances, they are taught in Penn State Harrisburg orientation that it is impolite in American society to discuss money (Penn State Harrisburg International Student Support Services, n.d.) They may have taboos in their own cultures regarding money as well.

\section{Libraries and Financial Literacy}

Financial literacy programming might seem like a topic for other offices on campus, but the library is the perfect home. In 2013, financial literacy was an Association of College and Research Libraries (ACRL) presidential initiative (Dawes, 2013), and academic librarians across the country continue to promote financial literacy education on their campuses (Reiter, 2015). The RUSA financial literacy guidelines provide libraries with an overview of the most important financial literacy concepts and ideas for related programming so that any library can address the financial needs of the community (Keller, LeBeau, Malafi, \& Spackman, 2015; RUSA, 2014). Given the rate of student borrowing and its impact on future financial decisions (Lin et al., 2016), college campuses are fertile grounds for growing financial literacy. 
At Penn State, only two courses listed in the general education undergraduate curriculum focus on consumer finance, and neither is required ("Quantification Courses," 2018; "Social and Behavioral Sciences Courses," 2018). Further, there are no curricular options for graduate students to learn this information. However, there are extracurricular opportunities, like those from the Sokolov-Miller Family Financial and Life Skills Center at University Park (UP), which offers in-person workshops to UP students and publicly available webinars to students at other campuses. Though all students, regardless of location, can make use of the online resources the Sokolov-Miller Center offers, those at the other 23 campuses across the state cannot easily attend the onsite financial literacy events. No coordinated programs offer in-person events at other campuses, providing an opportunity for the library to step in at Harrisburg.

\section{Teaching with Television}

Faculty across disciplines have used sitcom clips to demonstrate concepts in the curriculum or start a discussion. Gillis and Hall (2010) used clips from The Simpsons to teach economic policy concepts to undergraduates. The clips helped keep potentially controversial conversations on track: "Using a fictional, animated television show to discuss issues like organ donation makes it easier for students to set aside their normative concerns and focus instead on the positive effects of policy changes" (p. 85). Kilburn and Kilburn (2012) taught business concepts using clips related to management and marketing from 84 episodes of The Office. Because much of The Office demonstrates what not to do in business, a number of classroom exercises asked students to compare and contrast the television examples with business literature, or to critique and correct the behavior displayed in the clips (p. 23-28). At the end of the course, students said the clips were more effective than newspapers or magazines in raising their awareness of business concepts and reported that this teaching method made the class more fun while helping them learn (Kilburn \& Kilburn, 2012).

Television clips are useful teaching tools in the English Language Learning (ELL) classroom as well. Sitcoms can resonate with English language learners because they are a method of learning colloquial language and conversational English (Washburn, 2001). A television show like Friends is used for ELL because it is commonly known, and the conversations between the characters closely mimic "spontaneous face-to-face conversations" that students can expect in their daily lives (Frumuselu, De Maeyer, Donche, \& Colon Plana, 2015, p. 112).

Successful use of television clips as an active learning device has an impact in many subject areas. Clips can start a discussion, serve as a learning object, or even be a prompt for a writing exercise. With these ideas in mind, the author began to plan the session.

\section{The Program: Money Matters: A Financial Literacy Discussion}

Fun English Conversation is a weekly, extracurricular, skill-building English language group sponsored by ISSS. Topics and facilitators rotate, and the group primarily includes international students, with some native English speakers from the campus and community. Sessions are one hour long. ISSS invited the author to facilitate a session. A group of strangers, speaking many languages, with different cultural norms, would be talking about personal finances. What could go wrong? 
Approximately 20 people attend each session, but participants may change from week to week. Though the goal is for students to attend regularly and make friends, the drop-in design means that the participants may not all know each other, may not be friends, and may not even be peers, due to the presence of community members. This is especially true at the start of each semester, when new students arrive. The Money Matters session occurred in February. Creating a comfortable atmosphere for discussion was the ultimate goal, and the author focused on the international students as the primary audience when structuring the session.

Instead of hoping that students would open up about their own financial struggles during the session, the author sought a buffer. Comedy can lighten the mood, and money issues are common plot points in television shows. The author used clips from several shows and "Financial Literacy Education in Libraries: Guidelines and Best Practices for Service" (FLEL) (RUSA, 2014) to highlight important concepts and structure the session, showing examples of (mostly bad) financial behaviors that the group analyzed as part of a larger conversation about financial literacy on campus.

\section{Selecting Financial Literacy Guidelines}

Cultural taboos aside, international students studying in the US can face many financial challenges. Federal regulations make it difficult for international students to get a job and earn more money (Global Penn State, 2019), so they may live on a fixed, limited budget each semester. The author focused primarily on FLEL Guideline 4: Spending (RUSA, 2014). Due to regulations, it may be easier for international students to focus on budgeting and controlling spending than earning additional money. It is difficult, but not impossible, for international students to obtain a credit card in the US, so the session also included information from Guideline 2: Borrowing and Spending (RUSA, 2014) to encourage smart borrowing habits if students had credit. Program outcomes from FLEL included:

- Describing the difference between wants and needs

- Understanding the purpose of a budget

- Using credit knowledgeably and wisely

- Demonstrating how to set financial goals

\section{Selecting the Clips}

Popular television abounds with stories about money, and technology gives us endless opportunities to watch content, new and old. TV Tropes, a website dedicated to cataloging common story devices, features 205 tropes on its Money Tropes page; each trope is further documented with all of the times it has appeared on various television shows and other media ("Money Tropes," n.d.). The sitcom plotlines can serve as a stand-in for personal experiences and lead to an overall discussion about financial literacy and the resources available to students to improve their personal finances.

When selecting the shows and specific clips, the author used three main criteria:

1. Shows were easily accessible, meaning they currently aired, were syndicated widely, or were on a streaming platform

2. Shows were recognizable or relevant to students; they had seen them or heard of them before

3. The situation in the clip was relatable; if students were unfamiliar with the show, the content in the clip was broadly relevant 
Clips were selected from Friends, Sex and the City, Saturday Night Live, and Arrested Development. Friends is widely syndicated in the US, and airs in many countries; it currently streams on Netflix, along with Arrested Development. Arrested Development may be lesser known, but was recently revived with new seasons. It is also commonly referenced in internet memes. Sex and the City is syndicated and has two globally-distributed feature films. Saturday Night Live is one of the longest-running television programs in the US and streams on Hulu and the NBC website. The show features popular actors and musical artists each week, which can draw in additional viewers.

Before showing each clip, the author introduced financial literacy content related to the scene. After the clip, the author posed questions, and following the discussion presented additional financial literacy content before introducing the next clip.

\section{Session Overview}

The session started with a brief presentation about financial literacy and campus-based resources for more information. The author created a handout that defined financial literacy, explained budgeting and financial goal setting, and provided the contact information for our resources. Each clip was introduced with related financial literacy content based on the session outcomes. After showing the clip, the group answered the related discussion questions. Throughout the session, the author encouraged students to discuss only what they were comfortable with, and reminded them they did not have to use personal stories. Instead of personal stories, students were encouraged to use the situation from the clip, or examples from other people they knew or stories they heard.

Clip one. Friends, The One Where Monica Gets a Roommate (FriendsCompilationsAndClips, 2016)

In this clip, Rachel's friends encourage her to declare financial independence from her parents by cutting up her credit cards and getting a job. She was not prepared to live on her own and planned to marry a wealthy man who would take care of her. This clip is relatable for students because college is the first step in a journey of independence. People also often fantasize about becoming wealthy and no longer worrying about finances.

Financial Literacy Content:

- Define financial literacy

- Identify practices that demonstrate financial literacy: saving money, properly managing personal finances, planning for the future financially, paying down debt, investing money

Discussion Questions:

- Are you (or is Rachel) confident in your ability to manage your finances? Why or why not?

- What do you do to manage your finances? Do you have any tips to share?

Clip two. Saturday Night Live, Don't Buy Stuff You Can't Afford ("Don't Buy Stuff," 2006)

This clip features Amy Poehler and Steve Martin as a couple with a lot of credit card debt. Chris Parnell appears in an infomercial offering a book to help them, Don't Buy Stuff You Can't Afford. He explains the concept of saving for large purchases rather than using credit cards. 
Ticker: The Academic Business Librarianship Review, 4:1 (2019)

http://dx.doi.org/10.3998/ticker.16481003.0004.103

(c) 2019 Emily Mross

Financial Literacy Content:

- Define wants and needs

- Introduce proper use of credit: knowing when to use credit, paying off bills each month or as quickly as possible, understanding interest

- Introduce budgeting and financial goals

Discussion Questions:

- What do you hope to do in the future?

- How does money affect your (or Steve and Amy's) plans?

Clip three. Arrested Development, Charity Drive (Heyitsadriann, 2011)

Lucille Bluth is an out-of-touch formerly wealthy woman who does not understand what basic items, such as a banana, cost. Her son, who lives a more frugal life, admonishes her for not participating in basic adult behaviors, like grocery shopping.

Financial Literacy Content

- Explain budgeting concepts: knowing your monthly income and fixed costs, creating categories for needs and wants, knowing the costs of items you regularly buy

- Explain strategies for reducing costs for wants: borrowing materials from the library, using free public transportation, attending free or inexpensive events on campus/in the community

Discussion Questions:

- What are (your) needs? How much of your budget do you (or should someone) spend on them each month?

- What are (your) wants? How much of your budget do you (or should someone) spend on them each month?

- How do you stick to your goals for wants and needs, or how do you suggest people should stick to these goals?

Clip four. Sex and the City, Ring a Ding Ding (SATCclips, 2013)

Carrie needs money to buy her apartment and expects that Charlotte, her wealthy friend, will offer it to her. When Charlotte does not offer to help Carrie, citing Carrie's financial irresponsibility, they get in a fight.

Financial Literacy Content:

- Applying personal finance skills to manage money and save

- Knowing your personal boundaries in terms of borrowing/lending

- Everyone makes mistakes with money; we can learn from our mistakes

Discussion Questions:

- If you are comfortable, share a time you made a mistake with money. What happened and how did you fix it? 
- If you aren't comfortable sharing personally, do you know about someone who made a bad financial decision? What about Carrie and Charlotte's fight?

- Do you think they handled it well?

- What would you do differently?

The session concluded with reflection questions: What did you learn today? How will you apply new financial literacy concepts in your daily life? Do you have more questions or concerns?

Throughout the session, discussion was lively between all 20 participants and included large and small-group conversations. People laughed at the clips and seemed to enjoy them. The author did not conduct formal assessment, but based on observation, everyone stayed on topic. Some included the clip examples in their discussions, such as the fight over money from Sex and the City. In their answers to the reflection questions, students discussed the basic concepts of budgeting and saving, and how they planned to apply them. People mentioned library collections they could make more use of, including our DVDs, audiobooks, board games, and New York Times bestsellers.

\section{Conclusion}

Humor helped open the door for important discussions about money. Money Matters was the first in what is now a series of financial literacy workshops open to the entire campus. Since February 2017, Penn State Harrisburg Library has offered two financial literacy programs per semester focused on building financial literacy skills in budgeting, saving, loan repayment, investing, and preparing financially for life after college. Humor is incorporated into these sessions too, through the use of personal finance memes. The seven workshops have reached over 100 students. The workshops are offered in partnership with local banks, government agencies, and other financial partners who bring additional expertise to share with students. Workshop audiences include international and domestic students, and the workshops incorporate more formal assessment that allows students to identify problem areas and request new program topics. 
Ticker: The Academic Business Librarianship Review, 4:1 (2019)

http://dx.doi.org/10.3998/ticker.16481003.0004.103

(C) 2019 Emily Mross

\section{References}

Dawes, T. A. (2013). Libraries, ACRL, and financial literacy. College \& Research Libraries News, 74(9), 466-467. Retrieved from https://crln.acrl.org/index.php/crlnews/article/view/9007/9801

Don't Buy Stuff. (2006). Retrieved from https://www.nbc.com/saturday-night-live/video/dont-buy-stuff/n12020

Dunn, G. (2019). Bad with money. New York: Atria.

FriendsCompilationsAndClips. (2016, November 29) Friends - Rachel is cutting credit cards[Video file]. Retrieved from https://www.youtube.com/watch?v=mM3JLCHmwUQ\&feature=youtu.be

Frumuselu, A. D., De Maeyer, S., Donche, V., \& Colon Plana, M. del M. G. (2015). Television series inside the EFL classroom: Bridging the gap between teaching and learning informal language through subtitles. Linguistics and Education, 32, 107-117. https://doi.org/10.1016/J.LINGED.2015.10.001

Gillis, M. T., \& Hall, J. (2010). Using The Simpsons to improve economic instruction through policy analysis. American Economist, 55(1), 84-92.

Global Penn State. (2019). Employment. Retrieved from https://global.psu.edu/category/employment

Heyitsadriann. (2011, August 7). Lucille Bluth Banana Quote[Video file]. Retrieved from https://www.youtube.com/watch?v=NN_Qyk9DSUw\&feature=youtu.be

Keller, K., LeBeau, C., Malafi, E., \& Spackman, A. (2015). Meeting the need for library-based financial literacy education. Reference \& User Services Quarterly, 54(3), 47-51.

Kilburn, A. J., \& Kilburn, B. R. (2012). Linking the classroom to the living room: Learning through laughter with The Office. Academy of Educational Leadership Journal, 16(2), 21-31.

Lin, J. T., Bumcrot, C., Ulicny, T., Lusardi, A., Mottola, G., Kieffer, C., \& Walsh, G. (2016). Financial capability in the United States 2016. Washington, D.C. Retrieved from http://www.usfinancialcapability.org/downloads/NFCS_2015_Report_Nat__Findings.pdf

Lusardi, A., Michaud, P.-C., Mitchell, O. S., Mitchell, O. S., Angrisani, M., Brown, C., ... Wei, C. (2014). Optimal financial knowledge and wealth inequality (GFLEC Working Paper Series No. WP 2014-5). Washington, D.C. Retrieved from http://gflec.org///wp-content/uploads/2015/08/WP-2014-5-Optimal-Financial-Knowledge-and-WealthInequality.pdf

Money Tropes. (n.d.). Retrieved from https://tvtropes.org/pmwiki/pmwiki.php/Main/MoneyTropes

Myers-Walls, J., Frias, L., Kwon, K., Ko, M., \& Lu, T. (2011). Living life in two worlds: Acculturative stress among Asian international graduate student parents and spouses. Joumal of Comparative Family Studies, 42(4), 455-XIV. 
Ticker: The Academic Business Librarianship Review, 4:1 (2019)

http://dx.doi.org/10.3998/ticker.16481003.0004.103

(c) 2019 Emily Mross

OECD. (2017). PISA 2015 Results (Volume IV): Students' Financial Literacy(PISA). Paris: OECD Publishing. https://doi.org/10.1787/9789264270282-en

Penn State Harrisburg International Student Support Services. (n.d.). Guide to American culture and etiquette. Retrieved from https://harrisburg.psu.edu/international-student-support-services/guide-american-culture-etiquette

Penn State University Budget Office. (2019). Enrollment by ethnicity. Retrieved from https://budget.psu.edu/FactBook/StudentDynamic/minorityenrolbyethnicity.aspx?YearCode=2018\&FBPlusIndc=N

Poyrazli, S. \& Graheme, K. (2007). Barries to adjustment: Needs of international students within a semi-urban campus community. Journal of Instructional Psychology, 34(1), 28-45.

Quantification courses. (2018). Retrieved from http://undergraduate.bulletins.psu.edu/undergraduate/generaleducation/course-lists/quantification/

Reiter, L. (2015). Financial literacy and the academic library: Exploring the peer-to-peer approach. Joumal of Business \& Finance Librarianship, 20(1-2), 54-65. https://doi.org/10.1080/08963568.2015.977732

RUSA. (2014). Financial literacy education in libraries: Guidelines and best practices for service. Retrieved from http://www.ala.org/rusa/resources/guidelines

SATCdips. (2013, April 13). Sex and the City - Carrie and Charlotte's Big Fight [Video file]. Retrieved from https://www.youtube.com/watch?v=HuFzL5hZEW8\&feature=youtu.be

Smith, R., \& Khawaja, N. (2011). A review of the acculturation experiences of international students. International Joumal of Intercultural Relations, 35(6), 699-713.

Social and behavioral sciences courses. (2018). Retrieved from http://undergraduate.bulletins.psu.edu/undergraduate/general-education/course-lists/social-behavioral-sciences/

Washburn, G. N. (2001). Using situation comedies for pragmatic language teaching and leaming. TESOL Journal, 104), 21-26. https://doi.org/10.1002/J.1949-3533.2001.TB00045.X

Yan, K., \& Berliner, D. C. (2013). Chinese international students' personal and sociocultural stressors in the United States. Joumal of College Student Development, 54(1), 62-84. 